\title{
Remedies to illicit financial flows from transfer pricing of services and hosting intellectual property in Africa
}

\author{
Charles Goredema *
}

\begin{abstract}
Numerous reports in the last decade have focused on the challenges to African economies that emanate from the illicit transfers of funds and other valuable assets within some global corporations. A primary concern is the impact of these transfers on the taxable income of African subsidiaries. Two broad categories of intra-group transfers are of particular interest, partly because of the complexities they raise. One comprises transfers in payment of services exchanged among associated enterprises, while the other pertains to transfers by subsidiaries in payment of the value of intellectual assets attributed to the corporate centre of the global corporation. This article highlights the challenges raised by these transfers through case studies. It examines possible mechanisms to mitigate the challenges, drawing attention to current and impending developments. It concludes that there are good prospects for curbing illicit transfers linked to the examined types of transaction.
\end{abstract}

\section{Broad aims}

Transfer pricing transactions between associated enterprises for the exchange of services and hosting of intellectual property rights are important to governments primarily because of the potential of these transactions to impact on the distribution of taxable income. While multi-national corporations (MNCs) differ in size, complexity and global reach, a characteristic common to most is the opportunities they present for illegitimate transfers of income between tax jurisdictions.

* $\quad$ BL (Hons) (UZ), LLB (UZ), LLM (London) 
This article considers some of the strategies used to achieve such transfers in the last decade. The discussion is motivated by the observation that many subsidiary corporations tasked with providing services or hosting intellectual property rights are resident in low-tax jurisdictions. In many such instances, the intra-group distribution of responsibilities is influenced by low production costs, a favourable economic climate and low corporate tax rather than the extent of economic presence or business engagement. This article suggests policies and measures which affected countries may use to negate illicit transfers that are shrouded in intra-group trade. To the extent that some of these transfers are fraudulently or corruptly facilitated, the discussion seeks to contribute to anticorruption and anti-money laundering measures generally.

Tax collection impacts on the capacity of the state to deliver development and basic social services and is therefore an issue of enduring universal relevance. On average, between $24 \%$ and $37 \%$ of government revenue in developed countries is derived from individual and corporate tax. ${ }^{1}$ Corporate tax rates vary between countries, ranging from 19.2\% in Australia, 21.1\% in Switzerland, 25\% in the Netherlands, $25.2 \%$ in Norway, 34.4\% in France to as high as 39\% in the United States. ${ }^{2}$ Revenue yields from tax in African countries are generally lower, partly on account of ineffective tax collection. Abusive transfer pricing presents formidable challenges to effective tax collection. The last decade has witnessed an escalation of concerns about the use of transactions involving service-providing and rights-hosting corporations to erode the taxable income of related enterprises. ${ }^{3}$ Case studies from this period show that the amounts involved are usually quite significant.

This introduction is followed by the second part of the article, which describes the nature and scope of the potentially problematic services exchanged and the intellectual property rights that arise in intra-group transactions. The third part presents an overview of recurrent challenges that emanate from transfer pricing of services and hosting of intellectual property rights. It summarises the issues that these challenges raise. This is followed by an illustration of the issues through recent case studies. The fifth part suggests remedial recommendations.

\footnotetext{
Pomerleau K, Sources of government revenue in the OECD, 2014. http://taxfoundation.org/article/ sources-government-revenue-oecd-2014 on 9 November 2016.

Pomerleau, Sources of government revenue in the OECD.

United Nations Economic Commission for Africa, Africa Progress Report, 2013.
} 
The Report of the African Union's High Level Panel on Illicit Financial Flows from Africa (AU IFF Panel Report), which was adopted by the African Union (AU) at the beginning of 2015, forms part of the backdrop to this article. The report echoed the frustrations experienced by many African governments, inter-governmental organisations, labour unions, civil society structures and researchers at the slow progress in curbing illicit transfers of capital through questionable intra-group commercial dealings. These frustrations have often exposed gaps in policy and capacity. ${ }^{4}$

\section{Nature and scope of intra-group services and intellectual property rights}

The portfolio of services typically exchanged between associated enterprises includes research and development, management and human resources, information and communication technology (ICT), financing, insurance, marketing, and post-sale support. ${ }^{5}$ Legal and corporate advisory services may also be centralised at the corporate head office. ${ }^{6}$ Intellectual property rights are regarded as intangible assets. They may be derived from research and development, and housed in a single subsidiary. They include assets that are legally protected through registration, such as patents, trademarks, brands, logos and copyright. Equally intangible are non-registrable assets such as know-how, goodwill and reputation. In terms of Chapter 7 of the guidelines in use within the Organisation of Economic Co-operation and Development (OECD) region, an intra-group service is provided if a related corporation performs an activity for another, from which the recipient corporation gains economic or commercial value. Corporations are considered to be related if one of them either (a) participates directly or indirectly in the management, control or capital of the business of the other, or (b) a third corporate or natural person participates directly or indirectly

4 See, for instance, the Global Financial Integrity's reports Illicit financial flows from Africa: Hidden resource for development, 2009, 15-17; Illicit financial flows and the problem of net resource transfers from Africa: 19802009, 2013, 43-47; and Hiding in plain sight: Trade mis-invoicing and the impact of revenue loss in Ghana, Kenya, Mozambique, Tanzania and Uganda - 2002 to 2011, 43-49. See as well the Africa Progress Panel, Equity in extractives, 2013, 13-15.

5 For a general discussion of the economies of scale and economies of scope that underlie the geographic distribution of specialisation in global corporations, see Roach B, Corporate power in a global economy, 2007.

6 Roach, Corporate power in a global economy. 
in the management, control or capital of the business of both of them. ${ }^{7}$ The OECD formulation is widely accepted. ${ }^{8}$

There is no sector of business in which convoluted structures for the distribution of the functions of service provision and warehousing of intangible assets have not been created. The case studies considered in this article are in the extractives, manufacturing, agriculture and communications sectors, all of which are important sources of tax revenue, providers of employment and potential engines of growth. Questionable transactions have also been noted in the retail of construction equipment, ${ }^{9}$ hospitality ${ }^{10}$ and finance. ${ }^{11}$

\section{Recurrent issues and challenges}

The AU IFF Panel Report attributed up to $65 \%$ of illicit flows to pricing abuses within intra-group commercial trade transactions. ${ }^{12}$ The AU IFF Panel acknowledged the role of illegitimate cross-border payments for the exchange of intra-group services and intangible assets, in driving and/or enabling illicit financial flows. However, perhaps because of the narrow definition of illicit financial flows adopted, ${ }^{13}$ or of the challenges encountered by the AU Panel in accessing data, intra-group services and intangible assets did not receive adequate attention in the AU Panel Report. The AU Panel called for further research and 'improved generation of data on service-related transactions. ${ }^{14}$ A study conducted by the

See OECD guidelines for multinational enterprises, 2011.

8 In the 40 years of the existence of the OECD Guidelines, the number of countries adhering to them has grown from 24 to 46, which includes most sources of foreign direct investment to the developing world. See the 2016 Annual report on the OECD Guidelines.

9 For instance, the Caterpillar Inc case, which involved a global company with a presence in the US and Switzerland.

10 Some of the risks and opportunities pertinent to the hospitality sector are discussed in a general advisory issued in 2003 by CMS Law titled Brand Location and transfer pricing issues for hotel groups at http://www.cms-lawnow.com/ealerts/2003/11/brand-location-and-transfer-pricing-issues-forhotel-groups?cc_lang=en on 12 June 2017.

11 As illustrated in transactions between Zimbabwean telecommunications company Econet Wireless and its Mauritian-based associated company Econet Capital. They involved the purchase of equipment such as base stations for Econet Wireless by Econet Capital at a favourable price. Details are at http://www.techzim.co.zw/2017/02/econet-responds-tax-evasion-transfer-pricing-scandaldismisses-allegations-says-case-already-courts/ on 12 June 2017.

12 See the AU IFFs Panel Report titled Track it, stop it, get it: A report by the high level panel on illicit financial flows from Africa, 2015.

13 While accepting that activities that were unethical and/or corrupt could account for illicit flows, the AU IFFs Panel chose to define such flows as comprising 'money illegally earned, transferred or used.'

14 AU IFFs Panel Report Track it, stop it, get it, 68. 
Global Financial Integrity on illicit flows in developing countries during the decade 2005-2014 found that an average of 87\% of illicit financial outflows over that period were attributable to fraudulent mis-invoicing of trade. ${ }^{15}$

A primary concern of governments is whether the prices charged for services exchanged between related corporations within a MNC, resident in different tax jurisdictions, results in the illegitimate transfer of taxable income. Most instances involve the apparent imposition of excessive prices for services provided to one associated enterprise by another, which reduces the taxable income of the former. ${ }^{16}$

Several African countries whose tax bases are vulnerable to abusive transfer pricing lack the capacity to detect and interdict such practices. ${ }^{17}$ Among other organisations, the African Tax Administration Forum (ATAF) has identified transfer pricing as an issue of priority to all African countries. This coincides with the rise in public interest, as expressed by various civil society structures in Africa and across the world. The architecture of business entities from which the threat generally emanates can be identified. The case studies, a few of which are considered below, show high risk factors in MNCs:

- which consist of a network of associated corporations, related to each other as conceived in the OECD formulation;

- in which the bulk of business transactions by value or volume are intra-group;

- in which most such transactions occur under controlled conditions (relating to quality, fees and prices);

- which share an identifiable structure that manages the network, in particular to set prices used in the controlled transactions, and to determine the distribution of costs;

- which have at least one subsidiary tax resident in a favourable jurisdiction (defined by reference to status as a tax haven or secrecy jurisdiction);

15 Clough C, 'New study: Illicit financial flows in developing countries large and persistent' Global Financial Integrity Press Release, 1 May 2017.

16 PricewaterhouseCoopers, Transfer Pricing Perspectives, 2011, 19-21.

17 PricewaterhouseCoopers, Transfer Pricing Perspectives points out that 'although transfer pricing regimes based on the OECD Guidelines have been implemented in several African nations, many African nations have been slower to implement comprehensive transfer pricing regimes, often because of a lack of capacity and resources or a hesitation to adopt a model based solely on the OECD Guidelines.' 
- $\quad$ in which the income accruing to the latter subsidiary is disproportionate, when assessed against its contribution to the productive activities of the group.

Determining the economic substance of intra-group transfers for services or the value of intellectual rights is a recurrent issue. The issue is sometimes stated to be whether the associated enterprise from which payment is made has benefited to the extent claimed. The profiled Lafarge/Bamburi Cement Limited (BCL) case in Kenya, discussed later in this contribution, highlights this. While imported commodities can be observed and valued, this is not the case with services. It is even more difficult to assess the value that should be attributed to a brand or logo.

There may also be controversy about who rendered the service in question, or where the service was actually provided. A contentious issue in transfer pricing audits in India over the last decade concerns Indian-based affiliates of global corporations that undertake significant advertising, marketing, and promotion activities on behalf of their foreign holding companies, who then claim transfer of the costs of these marketing activities out of India. ${ }^{18}$ Occasionally, as in the case of LG Electronics India Private Limited, such claims have been rejected by tax authorities. $^{19}$

Another issue relates to the calculation of the value attached to the benefit for which the transfer price is paid. In other words, who should determine the value of an intellectual right, such as a brand? The MNC will invariably claim to know best the value of its intellectual property. In the costing of intellectual property rights, the comparable uncontrolled price method of assessing transfer prices requires consideration of whether an independent enterprise in comparable circumstances would have been willing to pay the value claimed for the right in question. The issue is who should bear the onus to prove it if the value is contested? In a few instances, tax authorities resort to a comparison of outcomes and putative contributions. In February 2017, for instance, South Africa indicated that the position would be that, where the pricing of intangibles that are difficult to evaluate is in issue, this would be determined by aligning the outcome of the transfer pricing to the value created. ${ }^{20}$

18 Tomar R, Makkar K, 'Transfer pricing controversies in the TMT sector in India' International Tax Review, 6 September 2013.

19 Tomar, Makkar, 'Transfer pricing controversies in the TMT sector in India'.

20 This was recommended by the Davis Tax Committee, and accepted by the Minister of Finance, as articulated in the Budget Review presented in February 2017. See http://www.gov.za/SPEECHES/ 
Limited knowledge not just of the sectors, but also of the global networks in which intra-group transactions occur, can significantly weaken regulatory capacity. Two realities necessitate this. The first is that intra-group transactions do not occur on the open market. Information which is not always readily accessible includes the global footprint of MNCs, as well as the identity of their beneficial owners. Unless compelled to disclose it, local subsidiaries generally do not volunteer information on their transactions with non-resident associates. Alexandra Readhead elaborates on the challenges of accessing the type of information required:

Revenue authorities need documentation from taxpayers to be notified of controlled transactions between the taxpayer and related parties and to determine whether these transactions were conducted at arm's length. The required information may include an organogram of the group, the value and type of related party transactions, as well as non-monetary transactions, and the transfer pricing methods used. From interviews in all five case-study countries (Ghana, Guinea, Tanzania, Sierra Leone and Zambia), getting hold of documentation from taxpayers appeared to be one of the most significant challenges to successful implementation of transfer pricing rules. ${ }^{21}$

Within the affected countries, information relevant to determining suspect transactions might be in the custody of disparate public institutions other than the tax authority. For instance, tax relevant information pertaining to the mining sector in Tanzania is also held by the Ministry of Energy and Minerals, the Tanzania Minerals Audit Agency (TMAA), the Ministry of Finance and the Office of the Auditor General. ${ }^{22}$ This broadens the scope for subsidiaries to be used for illicit cross-border transfers.

The second related challenge is that the jurisdictions in which the different components of the MNC are resident do not always perceive the impact of the transactions in the same way. As Readhead puts it, 'while the corporations gain from such tax planning, there are winners and losers between the countries involved.' ${ }^{23}$ The following sections highlight the manner in which these challenges have been encountered.

MINISTER-PRAVIN-GORDHAN-2017-BUDGET-SPEECH-22-FEB-2017-0000 on 30 July 2017.

21 Redhead A, Preventing tax base erosion in Africa: A regional study of transfer pricing challenges in the mining sector, Natural Resources Governance Institute, 2016, 13.

22 As observed by the author during research conducted in Dar es Salaam in March 2016.

23 Readhead, Preventing tax base erosion in Africa, 6. 


\section{Practical examples of transfer pricing challenges}

As is already clear, transfer pricing of intra-group services presents challenges to tax authorities. This section illustrates the challenges, beginning with management and information service fee transfers.

\subsection{MTN and management and information technology service fee transfers}

Claims raised against South African-based global telecommunications corporation MTN since 2011 highlight the significance of transfer pricing of intra-group services to various tax authorities. MTN has been accused of using subsidiaries that are tax resident in Dubai (MTN Dubai) and Mauritius (MTN International) to transfer income earned from its operations in Cote d'Ivoire, Ghana, Nigeria and Uganda. In support of the allegations, it is contended that:

i. MTN's operating subsidiaries in those four countries periodically transferred between $5 \%$ and $13 \%$ of annual turnover to MTN Dubai or MTN International in Mauritius for 'intellectual property rights and know-how' and for 'technical expertise and back-office support';

ii. MTN Dubai employed 115 people to provide management services to its non-South African and Middle Eastern subsidiaries including 'group procurement, group finance, legal services, human resources';

iii. MTN International had no staff, but received transfers for management fees re-routed from MTN Dubai - 55\% of the income received by MTN Dubai was passed on to MTN International; and

iv. MTN's own internal documents showed that it used the fees paid to MTN International partly to service international loans and partly to pay dividends to shareholders in South Africa. ${ }^{24}$

In 2011, the Uganda Revenue Authority (URA) demanded payment of $\$ 69$ million in alleged overdue tax from MTN Uganda. About $\$ 8$ million of the

24 MTN's intra-group transactions were jointly investigated by Amabhungane Centre for Investigative Journalism and Finance Uncovered. The report is summarised at http://amabhungane.co.za/ article/2015-10-08-ramaphosa-and-mtns-offshore-stash on 3 November 2016. 
claimed amount related to management fees paid to MTN International between 2003 and 2009. At issue was whether there was any economic substance to the transfers. ${ }^{25}$

Apart from the low staff numbers, and as the Amabhungane investigative journalists observed, MTN benefits from locating management services at MTN Dubai:

... as MTN does not operate any cellphones in Dubai, it will also have significantly lower costs than other MTN companies, as it does not need to pay for shops or the infrastructure needed to run a cellphone company. The picture is of a substantial amount of value being shifted from countries where MTN operates to Dubai, an emirate where the company enjoys a $0 \%$ tax rate. ${ }^{26}$

The resolution of the claim against MTN at the instance of the URA is particularly important as the telecommunications company also has a corporate presence in Benin, Botswana, Cameroon, Cote d'Ivoire, Cyprus, Ghana, Guinea Bissau, Guinea Republic, Iran, Liberia, Nigeria, Republic of Congo (Congo Brazzaville), Rwanda, South Africa, Sudan, Swaziland, Syria, Uganda, Yemen and Zambia. Its significance is further underscored by the fact that when challenged by the Nigerian Government in 2014, MTN reversed a substantial transfer for management fees, which would have been paid to MTN International in Mauritius. $^{27}$ The justification for the transfer was that it was for 'provision of intellectual property, know-how and other expertise to MTN Nigeria, ${ }^{28}$ notwithstanding that MTN International did not have any employees!

A similar reversal occurred in respect of management fees from MTN Ghana to MTN Dubai. ${ }^{29}$ In May 2017, the Rwanda Utilities Regulatory Authority

25 The URA informed the company that in its opinion: 'There is no evidence that the services purported to have been provided to MTN subsidiaries were needed by MTN Uganda. If MTN Uganda did not need those services, then it should not pay for them.' The information provided to URA with 'very little' evidence for the transfer, certainly not sufficient to justify a payment of $3 \%$ of MTN Uganda's turnover.

26 On MTN operations that have attracted scrutiny by tax authorities in Nigeria, see Mayah E, 'Investigation: How MTN ships billions abroad, paying less tax in Nigeria' Premium Times (Nigeria) 26 October 2015.

27 According to an investigation conducted by a consortium of investigative journalists, Amabhungane, and reported in Finance Uncovered at http:/ / www.financeuncovered.org/investigations/financeuncovered-investigation-mtns-mauritian-billions/ on 1 May 2016.

28 Quoted from the response from MTN to Amabhungane Investigative Journalists (AIJ) http://cdn. mg.co.za/content/documents/2015/10/08/mtnamabhunganecollatedresponses.pdf on 3 November 2016.

29 AU Panel Report, Track it, stop it, get it, 68. 
(RURA) imposed a penalty of $\$ 8.5$ million on MTN Rwanda for outsourcing IT services to MTN Uganda. The outsourcing violated its operating licence. ${ }^{30}$

\subsection{Eriksson and the supply, installation and maintenance of communi- cations equipment}

The 'MTN transactions' contrasted with the subject matter of the problematic transfers between Ericsson Kenya Limited (EKL) and related subsidiaries Ericsson Telefonaktiebolaget LM (ETLM Sweden) and Ericsson AB-Sweden (EAB). EKL is wholly owned by ETLM Sweden, which is in turn owned by $\mathrm{EAB} \cdot{ }^{31}$ In terms of contracts entered into by EKL and $\mathrm{EAB}$ with their common clients in Kenya, the group undertook to supply, install and maintain communications equipment (hardware and software). ${ }^{32}$ The equipment was sourced from EAB by EKL, which did the local installation, support and maintenance. ${ }^{33}$

EKL also offered various services on behalf of $E A B$ to other $E A B$ subsidiaries in East Africa, for which it charged a fee calculated at 5\% of the Full Cost Mark Up (FCMU). For the period 2007-2009, EKL declared a loss, which was confirmed by a tax audit by the Kenya Revenue Authority (KRA). ${ }^{34}$ In dispute was the cause of the loss. KRA contended that the losses were attributable to the extra-ordinary costs borne by EKL on account of its special relationship with the parent company, and should therefore be discounted through a transfer pricing adjustment. ${ }^{35} \mathrm{EKL}$ maintained that the costs were due to factors unrelated to its relationship to EAB. ${ }^{36} \mathrm{KRA}$ also contended that the transfer price charged by EKL for the services rendered on behalf of EAB was not appropriately benchmarked, and should be adjusted upward to $12 \%$ as an appropriate rate in comparable 'arms-length' transactions. ${ }^{37}$ In terms of the OECD Transferpricing guidelines, for a transfer pricing adjustment to be made, the primary consideration

\footnotetext{
30 The ruling was published on the website of the RURA at http://www.rura.rw/fileadmin/Documents/ICT/Laws/BOARD_DECISION_OF_12TH_MAY_2017_IM POSING_REGULATORY_SANCTIONS_TO_MTN_RWANDA_LTD_.pdf on 13 June 2017.

31 For a guide on the global footprint of Ericsson, see the corporate website at https://www.ericsson. com/en/about-us/company-facts/ericsson-worldwide\#K on 26 June 2017.

32 Ado M, 'Transfer pricing disputes in Kenya: Advance pricing agreement the way forward?' Unpublished Master's Thesis, Lund University, 28 May 2015, 21, 23.

Ado, 'Transfer pricing disputes in Kenya'.

Ado, 'Transfer pricing disputes in Kenya'.

Ado, 'Transfer pricing disputes in Kenya'.

Ado, 'Transfer pricing disputes in Kenya'.

Ado, 'Transfer pricing disputes in Kenya'.
} 
is whether a transaction price accords with the arm's length standard. ${ }^{38}$ The KRA has conducted dozens of tax audits between 2009 and 2015, and contends that it has uncovered an under-payment of tax of KSh25 billion. ${ }^{39}$ At the time of writing, the dispute had not been resolved.

The rather skewed inter-company relationship at the core of the Ericsson tax dispute resembles that of global commodity trading corporation Glencore and its Zambia based Mopani Copper Mines (Mopani). Mopani's dispute with Zambia Revenue Authority (ZRA) related to the period 2005-2009, and stemmed from its business transactions with Glencore. ${ }^{40}$ The transactions entailed reciprocal procurement - of machinery, finance and technical support from Glencore to or on behalf of Mopani, and copper ore from Mopani. ${ }^{41}$ Glencore was the sole customer of mineral output from the mines, at prices that were fixed for a ten-year period. Glencore subsequently refined and sold the copper to third party customers. ${ }^{42}$

Over a period of nearly a decade, Mopani Copper Mines did not return a profit, and therefore incurred no tax liability. ${ }^{43}$ The tax authority contended that this was the outcome of intra-company transfer mispricing. ${ }^{44}$ In other words, the losses reported over the period in question were attributable, partly to the sub-economic fixed prices at which the copper ore was sold and partly to the costs of equipment and services paid by Mopani. While the commodity transfer prices were fixed, the costs of equipment and services fluctuated. ${ }^{45}$ The latter costs were within the control of Glencore. In essence, Glencore was accused of transferring taxable revenue out of Zambia.

Thornton, which was hired to undertake an audit of Mopani by the ZRA, calculated the tax lost to the public revenue at $\$ 100$ million over four years. ${ }^{46}$

38 See also, United Nations practical manual on transfer pricing for developing countries, Second Edition, New York, 2017, 28.

39 Further details can be found at https://www.tralac.org/news/article/6087-kra-opens-new-battlefront-with-multinationals.html on 30 August 2016.

40 The pertinent details are set out in the audit report prepared by audit firm Econ Poyry with the assistance of Messrs. Grant Thornton in 2009 (the Econ/Grant Thornton audit report). The report can be accessed at https://miningwatch.ca/sites/default/files/Audit_Mopani.pdf on 13 June 2017.

41 See Econ/Grant Thornton audit report, cited above and as discussed by Christian Aid, in Glencore in Zambia: The tax questions that persist (the Christian Aid discussion) accessible at http://www.christianaid.org.uk/pressoffice/pressreleases/may_2015/glencore-in-zambia-the-tax-questions-thatpersist.aspx on 26 June 2017.

42 As admitted by Glencore itself.

43 Christian Aid, Glencore in Zambia.

44 Christian Aid, Glencore in Zambia.

45 Christian Aid, Glencore in Zambia.

46 The Econ/Grant Thornton Audit Report on Mopani Copper Mines was released in 2011. 
ActionAid estimated that the ZRA lost $\$ 123 \mathrm{~m}$ in each of those years. ${ }^{47}$ Since the exposure of these dealings, Glencore and Mopani have continued to repudiate the audit report, claiming that their dealings were conducted at arm's length. Despite the efforts of successive Zambian governments, non-governmental organisations and civil society pressure groups, the unpaid tax is still outstanding. ${ }^{48}$

\subsection{Bamburi and contentious valuation of intellectual property}

Intellectual property rights can be held in a different country to that in which they accrue. ${ }^{49}$ By agreement, fees can be transferred from the jurisdiction in which a subsidiary using a right is located to the jurisdiction in which the licence-holding subsidiary resides. ${ }^{50}$ As the Davis Tax Committee in South Africa pointed out

...profits can then be effectively shifted from the foreign subsidiary to the offshore patentowning company, which may end up paying little or no tax on the royalties received. Fees derived by the licensing and patent-holding company from the exploitation of the intellectual property will be either exempt from tax or subject to a low tax-rate in the tax-haven jurisdiction. ${ }^{51}$

While structuring a global corporation to centralise the hosting of intellectual property rights is not illegitimate per se, the problem arises where the value attributed to the rights are disproportionately greater than their contribution to the global income. ${ }^{52}$

The taxpaying subsidiary and relevant tax authorities were at odds over this point in the BCL case in Kenya. The dispute was precipitated by the Trademark License and General Assistance Agreement concluded between French cement manufacturer Lafarge and its Kenya-based subsidiary BCL. At issue was the justifiability of the fee charged to BCL. ${ }^{53}$ In terms of the agreement, BCL would

\section{Christian Aid, Glencore in Zambia.}

48 See 'Accusations of Zambia-Glencore Tax Cover-up' and the accompanying documentary prepared in 2013 on this case, which may be accessed at http://www.mining.com/accusations-of-glencorezambia-tax-probe-cover-up-80762 on 14 June 2017.

49 See generally, Archibugi D, Filippetti A, 'The globalisation of intellectual property rights: Four learned lessons and four theses' 1, Global Policy, 2, May 2010, 137-49.

50 Archibugi, Filippetti, 'The globalisation of intellectual property rights'.

51 Davis Tax Committee Interim Report 'Addressing base erosion and profit shifting in South Africa.'

52 This is the general contention in the Davis Committee report. In consequence, it recommended that corporates and tax authorities should ensure that transfer-pricing outcomes are aligned to the value created.

53 The contentions of the tax authority are summarised in the ruling of the Local Tax Committee at first instance. Michira M, 'Bamburi wins round one in Sh 1b tax claim case' The Standard, 21 October 2014. 
benefit from Lafarge's manufacturing know-how, trademark, logo and other support services. ${ }^{54}$ The fee was calculated at $2 \%$ of the BCL's consolidated net annual turnover. ${ }^{55}$

For the period between 2008 and 2012, the issues at the centre of the dispute were, firstly, whether the charges for intangibles should be combined with those for services and, secondly, whether deductions should be allowed for services in the absence of proof that they had been provided..$^{56} \mathrm{KRA}$ argued that each payment had to be proved to be linked to a corresponding service offered by Lafarge. ${ }^{57}$

A related issue was whether BCL should pay for use of the trademark and logo of Lafarge (comprising the inscription 'L-Lafarge') without showing proof that it had derived value. ${ }^{58} \mathrm{KRA}$ contended that the trademark and logo added no quantifiable benefit or value to BCL, and did not justify any transfer price. ${ }^{59} \mathrm{La}$ farge did not establish BCL, but acquired it from Blue Cement. ${ }^{60}$ It appeared that BCL had already established a dominant presence in the local market by then. ${ }^{61}$

\subsection{Transfers for management and financing}

Two studies by Action Aid on intra-group financial transactions within well-established MNCs further illustrate the issues at play. The first study analysed transactions among a network of subsidiaries of the Associated British Foods (ABF), which is active in the Zambian agricultural sector as Zambia Sugar Ltd (ZSL). ${ }^{62}$ The other examined a similar network centred around global brewer SAB Miller. ${ }^{63}$

\footnotetext{
Michira, 'Bamburi wins round one in Sh $1 \mathrm{~b}$ tax claim case'.

Michira, 'Bamburi wins round one in Sh $1 \mathrm{~b}$ tax claim case'.

Michira, 'Bamburi wins round one in Sh $1 \mathrm{~b}$ tax claim case'.

57 Michira, 'Bamburi wins round one in Sh $1 \mathrm{~b}$ tax claim case'. See also, Ado, 'Transfer pricing disputes in Kenya'.

58 Michira, 'Bamburi wins round one in Sh $1 \mathrm{~b}$ tax claim case'.

59 Michira, 'Bamburi wins round one in Sh $1 \mathrm{~b}$ tax claim case'.

${ }^{60}$ Michira, 'Bamburi wins round one in Sh $1 \mathrm{~b}$ tax claim case'.

61 There was no market survey or empirical study that was undertaken by either Lafarge or the KRA. The law was not clear as to where the onus to establish the value of the right claimed lies. See Michira, 'Bamburi wins round one in Sh $1 \mathrm{~b}$ tax claim case'.

62 ActionAid, Sweet nothings: The human cost of a British sugar giant avoiding taxes in southern Africa, 10 February 2013.

63 See 'ActionAid exposes tax dodging by UK brewing giant SABMiller, owners of Grolsch' ActionAid Press Release, 29 November 2010, announcing publication of ActionAid, Calling time: Why SAB Miller should stop dodging taxes in Africa, April 2012.
} 
ActionAid found that ZSL had paid out large 'management and secondment' fees to Illovo Sugar Ireland (ISI), an Irish sister-company. ISI appeared to have no physical presence in Ireland, in the sense of employees, infrastructure and overheads. Despite its rather obscure nature, ISI annually invoiced and received payment from ZSL for nearly $\$ 2.6$ million worth of management services for a number of years.

ZSL also paid an annual 'export agency' fee to another ABF subsidiary called Illovo Group Marketing Services (IGMS), which is based in Mauritius. Like ISI, GMS has no employees or infrastructure. The limited business presence echoed that one in the MTN transactions case, in which MTN International ostensibly rendered services from an unmanned office. In addition to the tax benefits of residence in Ireland and Mauritius, both of ZSL's sister companies had minimal expenses.

The report on transfer pricing within SAB Miller, Calling Time, focused on income derived from SAB Miller's subsidiary, Accra Brewery. One of the key findings was that it had 'more tax haven companies - a massive 65 - than it has breweries and bottling plants in Africa ... clever accounting allows it to siphon profits from the African and Indian companies to those in tax havens, a practice that ... may reduce its African corporation tax bill by as much as a fifth. ${ }^{64}$ The four methods identified, extensively described and analysed, were:

- Transfer payments for branding rights to a Rotterdam-based subsidiary, SAB Miller International BV - The latter benefits from tax concessions offered by the Netherlands that enable companies to pay next to no tax on royalties they earn;

- Transfer payments as management service fees to sister companies in European tax havens where effective tax rates are lower, mostly to Switzerland;

- Transfer payments to settle invoices for input procurement for Accra Brewery by Mubex, a subsidiary based in Mauritius - The tax rate in Mauritius is at least 20\% lower than that in Ghana; and

- Transfer payments to settle a loan extended to Accra Brewery by Mubex. The loan was more than seven times greater than Accra Brewery's capital. Repayment eroded the Brewery's income and correspondingly reduced its tax liability. ${ }^{65}$

\footnotetext{
ActionAid, Calling time, 6.

6 ActionAid, Calling time.
} 
Intra-group cross-border service transactions have attracted the attention of tax authorities in South Africa because of the recorded substantial annual transfers to pay for management, legal, accounting, administrative, financial, technical and commercial services. Over the four-year period 2008-2011, payments for intangible assets and related party services were made in the following categories: copyright, royalties and patent fees; legal, accounting and management consultancy; advertising and market research; research and development; architectural, engineering and technical services; and agricultural, mining and other professional services. These payments collectively amounted to just over R205.23 billion ( $\$ 15.73$ billion at June 2017 rates), about 50\% of which were attributed to legal, accounting and management consultancy fees.

\section{Remedial recommendations}

The regulation of intra-group commercial transactions in general and specifically in respect of services and intangible assets has become a universal policy issue. The complexities that are repeatedly raised in this sphere underline the need for effective legislation to stem abusive transfer pricing. In other words, the legislation should comprise certain minimum elements. It is important to re-define permissible transfer pricing activities, and, to the extent possible, distinguish them from the unethical and/or corrupt exploitation of differences between tax jurisdictions. Some of the activities exposed in the case studies referred to in this article appear to be fraudulent misrepresentations of international fund transfers as legitimate payment for services and for the value of intellectual property.

There are clear indications that voluntary taxpayer compliance with transfer pricing regulations cannot be taken for granted. As both the Africa Progress Panel and the ATAF have emphasised, governments have a responsibility to establish and equip structures to enforce compliance. It is equally their responsibility to set up tribunals to resolve disputed tax assessments in a timely manner. This points to the need for structured inter-agency information sharing and co-ordination. This is one of the arguments for preferring dedicated legislation rather than rely on provisions in generic tax legislation to regulate transfer pricing. Dedicated legislation holds out better prospects for creating specialised competence. Below are more pointed recommendations.

Recommendation 1: Every tax authority should establish a unit dedicated to monitor, detect and curb transfer pricing. Each unit should be equipped with transfer 
pricing expertise and technical sector knowledge to identify and evaluate transfer-pricing risks in all sectors considered susceptible. With the uptake of OECDinspired transfer pricing regulation across Africa, an increase in the establishment of specialized units is expected. Kenya and South Africa present examples of effective units. ${ }^{66}$

Recommendation 2: Each tax authority should establish a comprehensive database to use in transfer pricing tax assessments, which should ideally comprise: Information that emanates from the taxpayer, which is comprehensive and given timeously; information provided by other tax jurisdictions relevant to the transactions questioned - on tax paid by related subsidiaries in those jurisdictions, the physical presence of the subsidiaries, their expenses, among others; and information that is independently secured to be used in verifying the other information. The downside is that commercially developed databases, such as Orbis, are expensive. $^{67}$

The second element is based on the realisation that transfer pricing impacts on different tax jurisdictions, and that they may not become aware of its abuses at the same time. It should be addressed in a holistic manner. ${ }^{68}$ Automatic exchange of information involves the systematic and periodic exchange of routinely procured tax relevant information between jurisdictions in which different components of a MNC are tax-resident. The information deals with income (such as royalties, fees, and interest) and expenses (such as dividends, salaries, and pensions). In many instances, the information pertains to the business footprint of the subsidiary concerned.

Recommendation 3: The documentation that MNCs are required to maintain and submit to tax authorities should be standardised to facilitate and streamline cross-jurisdictional information-sharing. Standardisation should be followed and complemented by multi-lateral agreements that facilitate speedy exchange of information by tax authorities. The ATAF has proposed a framework for such cross-jurisdictional agreements. The South African Revenue Services has circulated draft rules that are based on the OECD transferpricing guidelines. They compel MNCs with a consolidated (group) turnover in excess of $\$ 72.5$ million to keep more detailed and compulsory records of their transfer-pricing transactions.

\footnotetext{
${ }^{66}$ Kenya has a Transfer Pricing Unit within the Large Taxpayers' Office. South Africa's Transfer Pricing Unit has existed within the Large Business Centre of the South African Revenue Service since 2012.

67 Costing as much as $\$ 50,000$ annually.

68 Ado M, 'Transfer pricing disputes in Kenya'.
} 
It is suggested that the common approach should compel corporate entities to disclose the identity and tax residence of enterprises to which they are related as defined in the OECD formulation. Furthermore, ATAF member states should emulate the EU in requiring information on revenues, profits, taxes paid, capital, earnings, tangible assets and the number of employees attached to each of the associated enterprises. The OECD has proposed that MNCs should keep a 'master file' of their subsidiaries, affiliates and related entities of the global company. In addition, there should be a 'local file' which documents transactions at the country level, and a comparative country-level report which sets out the allocation of income and taxes paid and the extent of the operations. ${ }^{69}$ This information can be used in verifying specific tax deduction expense claims.

Recommendation 4: African tax authorities should make greater use of Advance Pricing Agreements (APAs) with corporate taxpayers. The main strengths of APAs are: Their ability to pre-empt disputes over tax; they ensure that tax is collected when it falls due, thus avoiding the risk of the payment of tax being preempted by the liquidation of taxpayers; and they uphold taxpayer information confidentiality. APAs enable the protection of such information not only from third party disclosures, but also from use by the tax administration in subsequent audits or litigation where either no agreement is reached, or where the taxpayer, for some other reason, withdraws from the APA process

It is important that APAs are reached from an informed basis on both sides. The assumption is therefore that tax authorities equip themselves with the requisite skills and sector knowledge, so that they can make an input into aspects such as capping fees charged for management service, interest payments, etc.

Recommendation 5: African states should utilise joint commercial and industrial ventures with MNCs to curb abusive transfer pricing, disguised as payment of services and for intellectual property rights. State equity participation is not necessarily an effective instrument to tackle illicit financial flows (IFFs) from Africa. Such participation, in some instances, at the level of joint ventures, is becoming pervasive in the extractive sector. Angola, Zambia and Zimbabwe provide examples in oil and minerals. A common feature of the structures that have emerged in these sectors is that joint ventures and the corporations in which state equity has been acquired are in the upstream section of the value chain - in

69 Gumede W, 'How African countries lose billions in tax revenue through hidden cross-border trade' Mail and Guardian Africa, 12 September 2016. 
the case of oil, in the production of crude oil and natural gas. The nub of transfer mispricing is the existence of closed, vertically integrated MNCs involved in exploration and production, technological research, transportation of crude oil to refineries, and provision of financial resources. As long as there is scope for dispersing various functions to affiliates in different tax jurisdictions, the risk of transfer mispricing will persist. The Glencore/Mopani Copper Mines illustrates this. During the relevant period, the Zambian Government held $10 \%$ equity in Mopani through its investment vehicle, the Zambia Consolidated Copper Mines Investments Holdings. ${ }^{70}$ The other $90 \%$ was held by Carlisa Investments - which was registered in the Virgin Islands, a tax haven. ${ }^{71}$ Carlisa was in turn part owned by Glencore Finance $(81.2 \%)$ which was registered in Bermuda, and Sky-blue Enterprise (18.2\%) which was registered in the Virgin Islands. ${ }^{72}$ Glencore Finance is fully owned by Glencore International AG based in Zug, Switzerland. ${ }^{73}$ Sky-blue Enterprise is entirely owned by First Quantum Minerals of Canada. ${ }^{74}$ By the time that pre-tax income was declared, charges would already have been deducted for services and intellectual property rights!

Recommendation 6: Transfer mispricing should be criminalised. The AU IFFs Panel urged the adoption of 'clear and concise laws and regulations that make it illegal to intentionally, incorrectly or inaccurately state the price, quantity, quality or other aspect of trade in goods and services in order to move capital or profits to another jurisdiction or to manipulate, evade or avoid any form of taxation, including customs and excise duties.'

Recommendation 7: Legislatures and civil society should hold governments, particularly departments mandated to exercise oversight/supervisory responsibility and the treasury, accountable for monitoring and regulating transfer pricing.

${ }_{70}$ Christian Aid, 'Glencore in Zambia: The tax questions that persist' Press Release, 6 May 2015.

71 See World Investment News, 'Zambia: Company Profile of Mopani Copper Mines Plc' http://www. winne.com/zm/company-profiles/mopani-copper-mines-plc on 1 August 2017.

72 World Investment News, 'Zambia: Company Profile of Mopani Copper Mines Plc'.

73 World Investment News, 'Zambia: Company Profile of Mopani Copper Mines Plc'.

${ }^{74}$ World Investment News, 'Zambia: Company Profile of Mopani Copper Mines Plc'. 